\title{
IMPACT OF AGROLANDSCAPES DYNAMIC ON ENVIRONMENT OF THE KARELIAN ISTHMUS
}

\author{
Natalia Gouzel. \\ Saint-Petersburg State University, Russia
}

\begin{abstract}
During 10() last years the area of agricultural lands have reduced in 1,4 times on the Karelian Isthmus. It influences on environment and landscape image at the Karelian Isthmus very much. The processes of overgrowing of the former agricultural lands are studied on the landscapes base. Four stages can be revealed. Reestablish vegetation successions can be realised by different ways, with different rate, including various trees and ecological groups of species in different landscapes. In the different sites many traits in common are discovered during this processes.
\end{abstract}

\section{KEYWORDS}

Overgrowth succession; reforestation; abandoned agricultural lands.

\section{MAN AND LANDSCAPE}

Any region bears an imprint of natural processes and man's activity over a long period of time. The above relates to the agricultural landscapes of the area which are a result of the complex interaction of the area's nature, the population's householding practice and habits as well as of the economic and political situation. Historical events unfolding in the area - state and administrative border changes, ethnic changes and economic development - entail changes in the structure and functions of the agricultural landscapes. This, in turn, gives rise to new kinds of influences on landscapes and new strategies for their development.

In each historical epoch the inhabitants of a certain region establish their own relationship with the region's landscapes. In particular, this relationship is conditioned not only by the natural specificity of the landscapes but also by the inhabitants' ethnic background, the duration of their residence on a given territory (in particular, in the event of forced resettlements), the state it belongs to, the level of economic development and other factors. Depending on the factors listed above the natural potential of landscapes can be used with higher or lower efficiency. 


\section{METHODS TO BE USED}

The following groups of methods was be used to study the history of agriciltural development:

Historico-geographical methods: going analysis of maps dating from different times including those published in Russia and Finland at 1875, 1893,1996:

The present-day state and development trends of agricultural landscapes was be studied with the aid of:

1. Remote methods: analysis of outer space and aerial photographs

2. Field research:

- study of the available biodiversity in diffierent types of landscapes, with different methods and duration of the agricultural use of both land under cultivation and lands in different overgrowth stages;

- compilation of complex physico-geographic descriptions in key areas with dated anthropological influences (plowing up, termination of agricultural use, drainage, etc.). These descriptions, whose methodology has already been perfected by the author, must fix in detail the geological and geomorphological features of a given area, the characteristics of the substance migration regime and humidification conditions; the specific vegetation make-up, the composition of stands of trees, the soils of an area under investigation.

\section{CAUSES OF AGRICULTURAL LANDS DYNAMIC CHANGING AT THE KARELIAN ISTHMUS}

The Karelian Isthmus is a territory with an area of about 14 thousand sq. $\mathrm{km}$. located between Ladoga Lake and the Gulf of Finland in the north-west of European Russia. Karelian isthmus in post-war years has become important recreation region for quickly grow population of Leningrad - St.Petersburg.

The history of the agricultural development of the Karelian Isthmus connects with its complex political and ethnic history and also with a function of the landscape diversity of this territory and the natural variability of its natural conditions.

The territory has been under the control of different states over the last 500 years and has repeatedly changed its ethnic make-up, which led to changes in the use of agricultural land and the area of the lands under cultivation.

In Finland in 1939 year Karelian isthmus was one of the basic region of the intensive agricultural of milk-cattlebreeding direction, and then the part of the agricultural land achieved maximum for all period of assimilation. 
Very strong changes of the basic function and image of landscapes have become result of change of State membership of northern and central part of Karelian Isthmus in 1940 year and following social and economic processes

The last and the biggest of the ethnic changes occurred in the 30-s and 40-s of this century when the Finnish-speaking population was moved either to Finland or to other parts of the USSR and the vacated land was mainly settled by Slavic population from other regions of the USSR. Over the whole territory a collective and state farm system was introduced by force, which did not take into account the natural features of the territory. As a result of this considerable tracts of former agricultural lands were abandoned. First to be abandoned were small-contour lands as well as territories located far from important transport routes and requiring great effiorts for cultivation.

As a result of the reduction of such areas the abandoned tracts of land became largely overgrown.

\section{LANDSCAPEDIVERSITY AT THE KARELIAN ISTHMUS}

Karelian Isthmus is specially-heterogeneous territory. The processes of overgrowing of the former agricultural lands are studied on the landscapes base. The types of landscapes are distinguished on the based of the morphological relief symptoms, characteristics of the structure rock and the humid regime (3). 11 types of landscape are presented here, for example: granite ridges, sandy hills (kames), sandy, loamy, clayish plains, bogs e t c.

The purpose of investigation was to study the processes of overgrowing of the former agricultural lands in diffierent landscapes of the Karelian Isthmus.

In the natural zone of boreal forests, to which the Karelian Isthmus belongs, overgrowth processes on neglected agricultural lands are going on unequally in different types of landscapes. Four stages can be revealed of the processes of natural reestablishment of vegetation (2).

\section{OVERGROWTH SUCCESSIONS STAGES CHARACTERISTICS}

I - (period to $0 . .5$ from $15 . .20$ years after termination of agricultural use) - grass-herb meadow with unclosed brush (Salix phylicifolia L., S. aurita L., S. pentandra L., Frangula alnus Mill.) and regrowth (Betula pendula Roth., Alnus incana (L.) Moench., Populus tremula L., Sorbus aucuparia L.). Small cereals and motlley grass prevail in herb layer.

II - (15..20 - 25..40 years) - shrub layer with closed or low-closed canopy (Salix phylicifoliae, S. aurita, S. pentandrae, Frangula alnus, Sambucus racemosa L., Ribes nigrum L. ) and unclosed or low closed small-leaved regrowth (Betula pendula, Alnus incana, A. glutinosa (L.) Gaertn., Salix caprea L., Sorbus aucuparia, Pinus sylvestris L., Picea abies (L.) Karst., Padus avium Mill.). In the herbs layer meadow mesophytes and mesogigrophytes prevail as before; simultaneously forest edge mesophytes (Anthrriscus sylvestris (L.) Hollm., Aegopodium podagraria L.) and boreal 
herbs appear (Equisetum sylvaticum L., Calamagrostis arundinacea (L.) Roth.). Meadow mesophytes are decreased. Mesogigrophytes, gigrophytes, sometime forest edge and boreal species are increased.

III - (25..40 - 80 years) - closed small-leaved forest, (Alnus incana, Betula pendula, Populus tremula, Sorbus aucuparia, Padus avium) with total leaf cover $30-80 \%$, sometime including the coniferous trees (Picea abies, Pinus sylvestris). Forest structure depend on the type of landscapes (table 1). Shrub layer (with Frangula alnus, Ribes rubrum L., Sambucus racemosa) is developed less then on the Il stage (cover is not more than $10 \%$ ). Herb layer distinguishes from that on the II stage very much. Boreal species prevail, also some species of mesogygrophytes and forest edge species. Maximum nemoral species are presented (Anemone nemorosa L., Paris quadrifolia L.) in herb layer.

Table 1. Dynamic of reforestation on abandoned agricultural lands

\begin{tabular}{|c|c|c|}
\hline \multirow[t]{2}{*}{ Types of landscape } & \multicolumn{2}{|c|}{ Postagricultural successions } \\
\hline & III stage & IV stage \\
\hline Kames & $7 \mathrm{Al} 1 \mathrm{~B} 1 \mathrm{R} 1 \mathrm{~A}+\mathrm{P}$ & - \\
\hline $\begin{array}{l}\text { Sandy fluvioglacial } \\
\text { plains }\end{array}$ & $10 \mathrm{~B}+\mathrm{P}$ & - \\
\hline $\begin{array}{l}\text { Sandy-loam morainic } \\
\text { plains }\end{array}$ & $4 \mathrm{Al} 3 \mathrm{~B} 2 \mathrm{~F} 1 \mathrm{~A}$ & $4 \mathrm{~F} 4 \mathrm{P} 1 \mathrm{~B} 1 \mathrm{Al}$ \\
\hline Clay plains & $6 \mathrm{Al} 2 \mathrm{~B} 2 \mathrm{~A}+\mathrm{F}+\mathrm{P}$ & $4 \mathrm{~B} 3 \mathrm{P} 2 \mathrm{~F} 1 \mathrm{~A}+\mathrm{Al}$ \\
\hline Sandy plains & $6 \mathrm{Al} 3 \mathrm{~B} 1 \mathrm{~A}+\mathrm{P}$ & 8 P 2 B \\
\hline $\begin{array}{l}\text { Sandy plains with } \\
\text { excess moistening }\end{array}$ & $5 \mathrm{~B} 2 \mathrm{Al} 1 \mathrm{Alg} 1 \mathrm{~A} 1 \mathrm{~F}$ & - \\
\hline Mesotrofic peat-bogs & 7 B 2 P 1 Alg & $4 \mathrm{P} 3 \mathrm{~B} 3 \mathrm{~F}+\mathrm{Alg}$ \\
\hline
\end{tabular}

$\mathrm{Al}$ - alder (Alnus incana(L.) Moench.);

$\mathrm{Alg}$ - alder (Alnus glutinosa(L.) Gaertn.);

B - birch (Betula pendula Roth.);

$\mathrm{R}$ - rowan (Sorbus aucuparia L.);

$\mathrm{P}$ - pine (Pinus sylvesrtis L.);

A - aspen (Populus tremula L.);

F - fir (Picea abovata(L.) Karst.). 


\section{ECOLOGICAL TECHNOLOGY AND MANAGEMENT}

KALMAR, SWEDEN, September 22-24, 1999

IY - predomination of the coniferous trees (Picea abies, Pinus sylvestris) on small-leaved trees (Betula pendula, Alnus incana, Sorbus aucuparia). Shrub layer practically is not developed. In the herb layer boreal species (Oxalis acetosella L., Lerchenfeldia flexuosa (L.) Schur.) and forest edge mesophytes (Fragaria vesca L., Solidago virgaurea L.) prevail. Some meadow species are preserved. Moss-lichen layer is developed under the canopy of forest. Cover of moss-lichen layer - to $80 \%$.

Overgrowth processes on the bog realise differently, combining symptoms of forest restoration and swamping. Swamping processes arise from drainage stopping.

Reestablish vegetation successions can be realised by different ways, with different rate, including various trees and ecological groups of species in different landscapes. In the different sites many traits in common are discovered during this processes.

The processes taking place in soil of abandoned agricultural lands are expressed more poorly than in vegetation as soil is more "conservative" element of landscape.

\section{CHANGING THE AREAS OF AGRICULTURAL LANDS}

The process of reduction of agricultural lands have taken place some decades in the NorthWestern European Russia. During 100 last years the area of agricultural lands have reduced in 1,4 times on the Karelian Isthmus. In 1890 the area of agricultural lands was $20 \%$ of the Karelian Isthmus area. The most part of it had been abandoned after change of State border after of the Second World War. Now abandoned agricultural lands occupy $7 \%$ or $1000 \mathrm{~km}^{2}$ of the areae(1).

Dynamic of changing agricultural lands influences on environment and landscape image at the Karelian Isthmus very much.

Over the last decade because of a change in the socio-political situation there has emerged a tendency towards an increase in the area of the cultivated land in the Karelian Isthmus including the secondary development of previously abandoned lands. However, this process is going on spontaneously; there are quite a few cases of the use of woodland valuable in recreational and forestry respects for dacha or country-cottage construction.

From fast change the pattern of ownership on ground is necessary urgent inventory of being available ground resources, including with the purposes of creation of new especially protected territories. It is important to emphasise, that to guards should be subject not only sites so-called quot.; untouched quot.; a nature, but also area with different overgrowth succession stages agricultural lands, where biodiversity raises. 


\section{LIST OF REFERENCES}

1. Gouzel N. (1998). Landscape analysis of change agricultural development in the Karelian Isthmus area. Vestnik St.Petersburg University, 7, 2(14), 102.106.

2. Gouzel N., Reznikov A. (1998). Landscape analysis of reforestation on abandoned agricultural lands of the Karelian Isthmus. International Conference "Ecology of taiga forests", Syktyvkar

3. Isachenko, G., Reznikov A. (1996). Taiga of the European Russia North-West: Landscape dynamics. St.Petersburg, Russia, pp.33-37. 